\title{
A NATOLIAN
}

\section{STUDIES}

Journal of the British Institute of Archaeology at Ankara

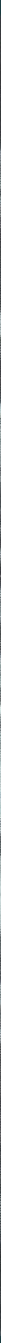

Published annually by

THE BRITISH INSTITUTE OF ARCHAEOLOGY AT ANKARA 10 Carlton House Terrace, London SW1Y 5AH 
The Institute was founded in 1948 and exists to support, promote and publish British research into the archaeology and related subjects (e.g. anthropology, geography, history, art history, literature and languages) of Turkey and surrounding regions such as the Black Sea littoral.

A small staff at the Institute's premises in Ankara, headed by Dr Hugh Elton as Director, conduct their own research, assist scholars and maintain the Institute's research resources. The premises in Ankara are a centre for research and house a library of approximately 42,000 volumes and important collections of faunal and botanical reference material, sherds, squeezes of inscriptions, photographs/slides and excavation archives. These resources, together with a laboratory and computer services, are available free of charge to members of the Institute. The Institute is able to offer to members, for a reasonable charge, the use of accommodation, surveying and photographic equipment, and vehicles.

Sixteen fieldwork projects, as well as post-fieldwork, Institute-based and museum-based research, and publication projects, are currently sponsored by the Institute. Excavations presently supported include those at the Neolithic site of Çatalhöyük directed by Ian Hodder of the University of Cambridge, at the Byzantine city of Amorium directed by Chris Lightfoot of the Metropolitan Museum of Art, New York and at Pichvnari in the Republic of Georgia directed by Michael Vickers of the Ashmolean Museum and Amiran Kakhidze of Batumi Archaeological Museum. Surveys range from the multi-period Konya Plain Survey directed by Douglas Baird of the University of Liverpool, to the investigation of the Iron Age city of Kerkenes Dağ by Geoff Summers of the Middle East Technical University, to the study of the Byzantine Anastasian Wall and associated features conducted by Jim Crow of the University of Newcastle upon Tyne.

Subscription to the Institute costs $£ 30$ per annum ( $£ 15$ for students and those who are unwaged). Members are entitled to copies of the Institute's journal, Anatolian Studies, and of its annual publication on current research, Anatolian Archaeology, a discount on other Institute publications, notification of conferences and lectures, and access to the library, accommodation and other facilities in Ankara.

To join the Institute, or for further information about its work, please contact us at British Institute of Archaeology at Ankara 10 Carlton House Terrace, London SW1Y 5AH

Emailbiaa@britac.ac.uk

Web site www.biaa.ac.uk

Back copies of Anatolian Studies are available from

Oxbow Books, Park End Place, Oxford OX1 1HN www.oxbowbooks.com

Cover photo: Alahan east church, late fifth century, looking west from the apse (photo: Hugh Elton). See 'Alahan and Zeno' by Hugh Elton 


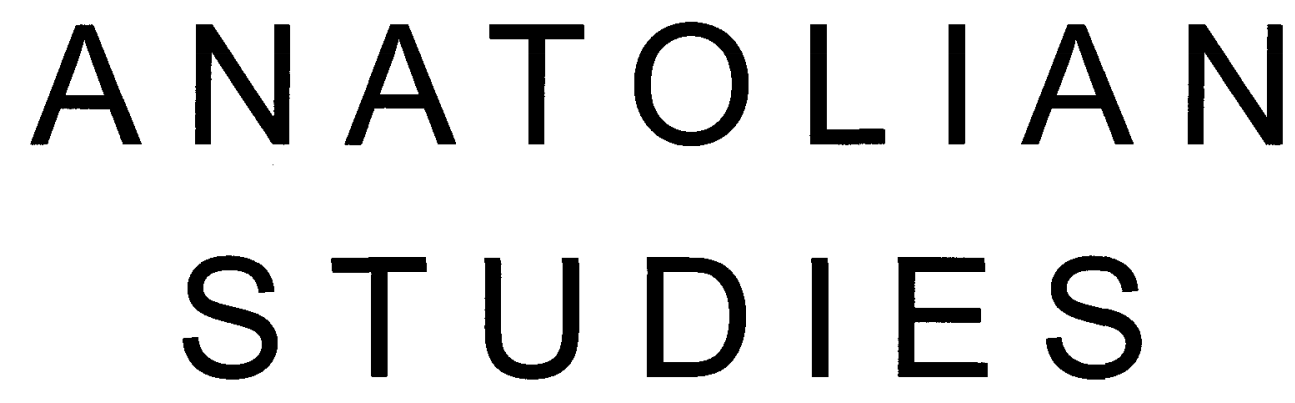

Journal of the British Institute of Archaeology at Ankara

\section{Contents}

Water mills in the area of Sagalassos: a disappearing ancient technology

K. Donners, M. Waelkens and J. Deckers

The Upper Tigris Archaeological Research Project: a final report from the 1999 field season

Bradley J. Parker and Andrew Creekmore, with contributions by Chiara Cavallo, Rik Maliepaard and Richard Paine

Troy in recent perspective

D.F. Easton, J.D. Hawkins, A.G. Sherratt and E.S. Sherratt

Lydian painted pottery at Daskyleion

R. Gül Gürtekin-Demir

Pisidia Survey Project: Melli 2000

Lutgarde Vandeput and Veli Köse

Hugh Elton

Published annually by

THE BRITISH INSTITUTE OF ARCHAEOLOGY AT ANKARA

10 Carlton House Terrace, London SW1Y 5AH 


\section{EDITORIAL BOARD}

Dr S. Campbell (University of Manchester)

Dr J.J. Coulton (University of Oxford)

Dr Hugh Elton (British Institute of Archaeology at Ankara)

Dr Stephen Hill (University of Warwick)

Dr Tamar Hodos (University of Bristol)

Professor J.M. Wagstaff (University of Southampton)

\section{ACADEMIC EDITOR}

Professor A.A.M. Bryer (University of Birmingham)

\section{EXECUTIVE EDITOR}

Gina Coulthard (British Institute of Archaeology at Ankara)

Anatolian Studies is a refereed journal

Articles for publication, requests for Notes for Contributors and other correspondence should be addressed to

The Executive Editor, Anatolian Studies

British Institute of Archaeology at Ankara

10 Carlton House Terrace, London SW1Y 5AH

Email biaa@britac.ac.uk

With acknowledgements to The Society of Dilettanti

(C) British Institute of Archaeology at Ankara 2002

ISSN 0066-1546

All rights reserved. No parts of this publication may be reproduced, stored in a retrieval system, or transmitted, in any form or by any means, electronic, mechanical, photocopying, recording, or otherwise, without the prior permission of the British Institute of Archaeology at Ankara.

Printed by Stephen Austin \& Sons Ltd, Hertford 